\title{
Research and Practice on the Information and Communication Technology Personnel Training Mode based on CDIO Pedagogics
}

\author{
Wenzhun Huang \\ Department of Electronic Information Engineering \\ Xijing University \\ Xi'an, China \\ e-mail: huangwenzhun@xijing.edu.cn
}

\author{
Shanwen Zhang \\ Department of Electronic Information Engineering \\ Xijing University \\ Xi'an, China \\ e-mail:wjdw716@163.com
}

\begin{abstract}
In this paper, we conduct research on the information and communication technology personnel training mode based on CDIO pedagogics. Personnel training mode is to point to in certain education under guidance of the thought and the concept to the talent training including dynamic ontology. Expounds the basic concept of engineering education mode CDIO was proposed based on CDIO education model of integrated project reform exploration and practice, and the requirement of experimental project involved in this paper. Teachers and students are in the experimental teaching in great changes of the role, requests the student to independently design and complete the experiment content implementing the students passively accept education to the students' independent innovation and design and implementation of change. In the future, more research will be conducted to optimize the current CDIO education pattern for optimal teaching approach.
\end{abstract}

Keywords-CDIO Pedagogics; Personnel Training; Information and Communication; Education

\section{INTRODUCTION}

The personnel training mode is the same education activity itself exists at the same time. In order to realize training target, people in education activities is bound to choose a certain way, method, choose the corresponding education contents, at a particular place or environment. By specific personnel to organize their implementation, the training mode of connotation can be defined as follows.

Personnel training mode is to point to in certain education under guidance of the thought and the concept to talent training including dynamic ontology. Although people explain a variety of personnel training mode, the connotation of higher vocational education personnel training mode must include the seven basic elements. (1) Talent cultivation way is talent cultivation is to realize talents training process, training task, achieve goal of cultivating basic channels. Universityenterprise cooperation purpose is to build the business teaching environment, under the support and participation of industry enterprise and make teaching environment as much as possible close to the professional environment so as to complete work-integrated learning personnel training process. (2) Talents evaluation refers to according to certain criteria, such as the quality of personnel training and performance measurement. The diversification of evaluation indexes, namely, the comprehensive evaluation index of diversity. Evaluation index is the basic standard of talent training evaluation, the diversification of evaluation subject and evaluation way decided to the diversified characteristics of the evaluation index which requires to establishing the diversity index system. (3) The courses in the higher vocational education personnel of training content, higher vocational colleges and industry enterprise according to the requirements of the technology and the professional post office with reference to the corresponding professional qualification standards cooperation development, highlight the professional quality and skills. (4) The determination of higher vocational education personnel training mode must to cultivate high skilled talents' the total target of the basic basis according to the setting of professional and the professional training goal. (5) Any when determining personnel training mode in higher vocational colleges must be in accordance with the requirements of the service to the local economic and social development to foster in the service of the local production, construction, service and management first line need skilled talents as the main direction. (6) Training process is designed for the realization of training objectives and make the training content to carry out teaching activities, it is the key to the personnel training mode into practice. Work-integrated learning throughout course of the cultivation of talents is an important characteristic of higher vocational education personnel training process. (7) In the higher vocational education should be guided by regional economic development and industry development by being flexible as the main body with work-integrated learning as the carrier of the talent training system especially in accordance with the requirements of the program "system ethics". Strengthen the management system of procedural and make the flexible system more in line with the objective requirement of the higher vocational education [1-3]

CDIO engineering education pays attention to cultivate the students to master the solid basic theory and professional knowledge and on the basis of general education process into the specific situation of engineering field to develop students' 
comprehensive quality and ability. The professional teaching reform based on the CDIO engineering education concept can make the application of electronic technology teaching implementation "excellence initiative" to the requirements of training courses. In the following figure, we illustrate the principles of the CDIO organization structure.

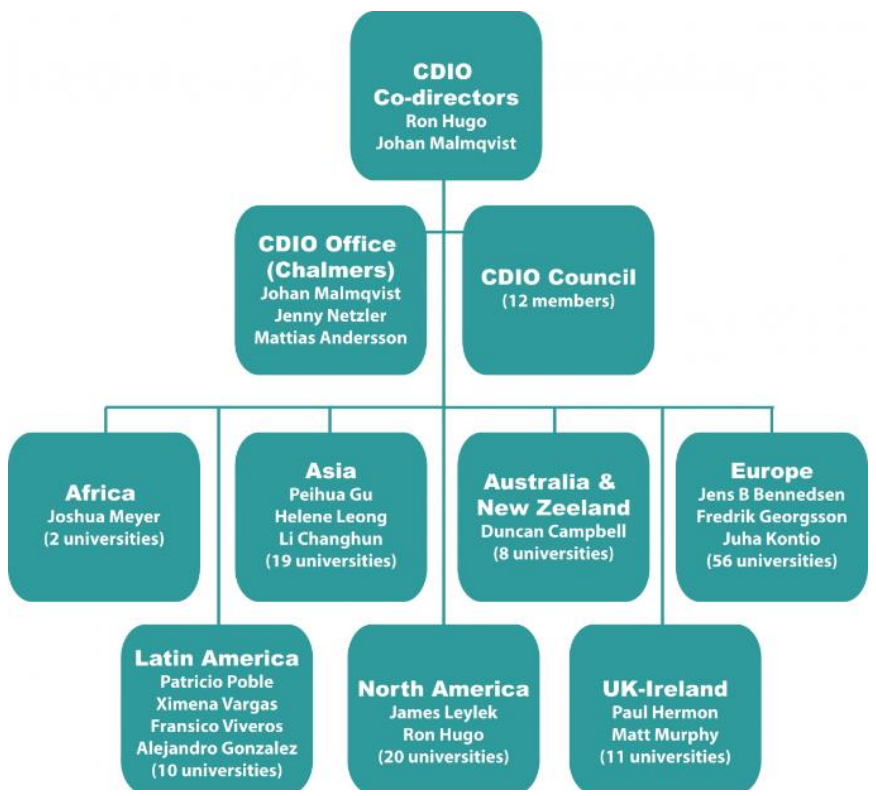

Fig. 1. The Principles of the CDIO Organization Structure

In this paper, we conduct research on the information and communication technology personnel training mode based on CDIO pedagogics. Information technology as an important force to promote social progress and promoting development of science and education has received the unprecedented attention. For all kinds of schools, using the modern information technology curriculum reform and the reform of the teaching methods and promoting education reform so as to cultivate a good task of information literacy of modern talent is imminent. In the next sections, we will analyze the mentioned issues from the perspective of theory and applications.

\section{The Proposed Methodology}

\section{A. The CDIO Pedagogics and Standards}

CDIO engineering education mode and the general concept of entrepreneurship education is the reflection on traditional education mode and reform. Traditional education pattern obsolete teaching content and more away from the actual, single teaching mode, with teachers' knowledge is given priority to evaluation knowledge oriented and ignore the ability training. The passive learning method causes the student to understand superficial learning contents, lack of long-term learning motivation, learning motivation to develop innovation spirit and practice ability. Engineering ability not only contains the personal academic knowledge, but also contains a lifelong learning ability, team communication ability and system control. As a guide the engineering education personnel training mode reform of education ideology and curriculum design system, the framework of
CDIO accords with the general law of modern engineering technology applied talents training which has good development prospect and promotion value. Its core is that according to the engineering requirement for students' knowledge, ability and quality in engineering design as the guide to project training as the carrier to set up the course and teaching mode. In the following list, we demonstrate the primary principles of the CDIO education pattern.

- Emphasizes comprehensive innovation ability and the social coordinated development mode. Cultivating engineering students' innovative ability is improving the effectiveness of higher engineering education and the basic guarantee. Modern any engineering problems is no longer a pure independent discipline or field problem, need to apply other disciplines of knowledge and skills. The information society of today and almost all engineering fields of science and technology bear the stamp of information science. With the rapid development in science and technology, kinds of division of labor will become thin and need multiple jobs skills closely to ensure the success of the project research and development [4].

- Strengthen the professional basic education at the same time focus on the engineering practice, strengthen practice. If the university is a platform to learn and progress, then the platform's foundation is the basis of college courses. So, to learn and master the basic knowledge and basic course range of this professional requirement is very important. Because in today's rapid development in the science and technology, many of the seemingly advanced technology in the application fields in a few years will be replaced by new technology or tool, only grasp solid basic knowledge can be a lifetime. On the other hand, if we don't have to lay a good foundation, it is difficult to understand the more complex or the application of the advanced technology for the future career development and improve would be a huge obstacle.

- Basic specialized knowledge is static and it can't direct the resulting solution to the practical problems, the need to identify problems, engineering reasoning and the method to solve the problem, is the flexible in the practical work of dealing with various problems. Engineering technology is a practical area and stay on idea of conceptual phase is reflected into directly the productivity of its engineering and social value [5].

It is proposed based on CDIO mode of project development and independent innovation research and development of the comprehensive experiment has broken the traditional experimental teaching mode. Teachers and students in the experimental teaching in great changes of the role and requests the student to independently design and complete the experiment content, students change from passive to accept education to independent innovation with the design and implementation of change.

\section{B. The Reform of Teaching and Education Pattern}

In the college students' research of learning should pay attention to scientific research and education. The realization of goal requires attention to cultivate the students independent thinking, independent learning and ability to work independently, work well with people and the cultivation of 
the ability, must pass through the student, practice can achieve on their own. So, college students should pay special attention to the cultivation of research ability, lets the student in the process of science education through a workout. Scientific education is to adapt to the requirement arises at the historic moment.

Personnel training mode is to point to in certain education thought under the basic guidance of the theory, according to the positioning of running school to cultivate the student knowledge ability and quality structure of design and realize the goal of the organization and operation mode. Specifically, it embodied the university personnel training target, education system, course content, teaching process, the combination of various factors, such as is the strategy to realize training target system. It is the study of teaching works in nature and is designed or the students in the colleges and universities to construct knowledge, ability and quality structure and fundamental way to realize this structure. The modern reform of the education should focus on the following sections.

- Train applied innovative talents involved in all aspects of the society and the whole process of education need to establish a complete teaching system. From enterprises employ a number of stable high levels of teachers including enterprise intern teachers and mentor. Enterprise intern teachers to guide students in the enterprise practice activities; Enterprise instructor for the teaching of the course in university teaching courses, seminar and concentration. Enterprise is mainly responsible for students' graduation design guidance to cultivate the student's ability of engineering practice. Reform of traditional experimental teaching mode and method, in order to replace comprehensive experiment and designing experiment validation experiments with independent experiment instead of the passive imitation experiment [6].

- By the way of match well of Chinese and western education, the use of domestic and foreign high-quality education resources to cultivate international talents, can effectively cope with the globalization of economic development. According to students' cognitive process and the theory of teaching process, the practice teaching link runs through the whole learning process of students around the class specialized training goal and ability request, through the concise professional practice chains, maximize students' learning initiative and interest in learning and pay attention to training students to analyze and solve problems of logical thinking ability with innovation ability and technical application ability and social adaptation ability.

- The Internet changed the way students learn with time and space with the rapid development of institute of lead frame open teaching mode, to cultivate students' interest in learning and self-study habit is important. Implementation of theory teaching system and practice teaching system of integration design method, theory of practice teaching through the teaching process, the height of the realization of teaching theory and practice of integration. Setting up a series of comprehensive practice curriculum, in the process of project completion to cultivate the students' innovative design concept and practical ability.
On teaching content, it should broaden the professional knowledge, with the development of the discipline closely related; Increased investment in related professional, break the barriers between disciplines, lets the student can more choice learning content; The introduction of critical teaching, raises the student independent thinking and autonomous learning ability; Through scientific learning theory knowledge, causes the student to master the methods of scientific research, stimulate their interest, cultivate the scientific research enthusiasm. According to their aptitude should be taken in the teaching mode to make every student teaching and give the full consideration to their personal knowledge of the differences between demand and their own. In a series of plans and goals and to make them match the social needs of different talents with diversification of teaching mode to let the students according to their own needs to choose the most suitable model for learning.

\section{The Novel Information and Communication Technology Personnel Training Mode}

In recent years, our country's higher vocational education vigorously, has trained a large number of high-quality skilled talents for modernization construction made great contribution to the popularization of higher education, but also has many problems, as things look, on the one hand is a communication enterprise need people, training of higher vocational education, on the other hand is a post and out of a large number of graduate employment difficulty. Investigate its reason, mainly is the post class in higher vocational education to cultivate the graduates lack professional ability, especially the practice ability and the ability to solve practical problems. The existing of post and telecommunications class in higher vocational college especially mobile communications professional majority of communication engineering exist obvious deficiency [7].

Fuse abroad and other parts of the China universities of the professional division is very detailed, professional characteristic, highlight its advantages and professional characteristics to give students the choice of diversification. On training target, establish information technology oriented, oriented management, information resources oriented training objectives with clear professional talents should have the knowledge and basic quality, makes the teaching and practice teaching specific goals. Fuse professional talents should possess inter-disciplinary talent of the characteristics and advantages, both computer professionals lack of quality management, and management personnel lack of information technology application ability. Professional setting inevitably leads to the reconstruction of the course system of innovation, to develop cross-century information management talents, it is necessary to optimize the traditional curriculum system, set up reasonable structure, clear goal curriculum system. Information management professional course system setting is the basic idea of modularization.

It is all the courses according to certain standards are divided into several independent modules and they can be separately used in teaching. At the same time in order to promote teaching, in order to promote learning, it is also conducive to the development of students' skill teaching 
auxiliary. Method of part in all kinds of skills contest to organize students to sign up for, distribution of instructor for guidance and through the contest organization of the classification, create a variety of extra-curricular interest groups, make students have more opportunities to make actual exercise. The teacher provides students with three-dimensional teaching resources with the use of the network will be extended to extra-curricular and classroom teaching make full use of network resources for learning [8].

\section{CDIO Standards \& PDCA}

\begin{tabular}{|c|c|c|}
\hline Score & Description & PDCA \\
\hline 5 & $\begin{array}{l}\text { Evidence related to the standard is regularly reviewed and } \\
\text { used to make improvements. }\end{array}$ & \multirow[b]{2}{*}{ C } \\
\hline 4 & $\begin{array}{l}\text { There is documented evidence of the full implementation } \\
\text { and impact of the standard across program components } \\
\text { and constituents. }\end{array}$ & \\
\hline 3 & $\begin{array}{l}\text { Implementation of the plan to address the standard is } \\
\text { underway across the program components and } \\
\text { constituents. }\end{array}$ & (D) \\
\hline 2 & There is a plan in place to address the standard. & \multirow{2}{*}{ P } \\
\hline 1 & $\begin{array}{l}\text { There is an awareness of need to adopt the standard and a } \\
\text { process is in place to address it. }\end{array}$ & \\
\hline 0 & $\begin{array}{l}\text { There is no documented plan or activity related to the } \\
\text { standard. }\end{array}$ & \\
\hline
\end{tabular}

Fig. 2. The Principles of the Novel Training Mode

In the above figure 2, we demonstrate the principles of the novel training mode. Interest is the best teacher and is to promote the students' motivation directly. In the information technology teaching to cultivate the students' interest in learning, it also is the necessary condition to inspire creativity. Ask students to much more saying that should actively participate in the teaching process, enable students to learn in a happy atmosphere, is to mobilize students study enthusiasm, improve the teaching effect is the important condition of information technology, information technology teaching key of success or failure in the experiment. It can give full play to their talents to create has invented. Therefore, in the teaching process, the information technology is one of important tasks of teachers is to stimulate students' interest in learning. The combination of the Internet resources with the CDIO teaching way will enhance the traditional CDIO based teaching methodology.

\section{CONCLUSION}

In this paper, we conduct research on information and communication technology personnel training mode based on CDIO pedagogics. Based on boost students' ability to perform under the condition of interpretation by the concept of CDIO for the initiative and the way of the innovation of electrical engineering, we through to the initiative and electrical engineering professional obtain employment prospect analysis and gives a project required by the enterprise as a key sector of education teaching strategy. The large engineering and integration of education teaching makes a cultivating "engineer" on the spot in the way of practical progress in institutions of higher learning. CDIO is a kind of new education pattern of the current engineering education, it is to train applied talents as the goal. The CDIO engineering education concept after recent more than ten years of research and application has become today's advanced concept, systemic strong with the wide scope of the application of modern engineering education mode. Our research combines CDIO pattern with the state-of-the-art method to enhance and optimize the traditional education pattern.

\section{ACKNOWLEDGMENT}

This work was financially supported by the 2015 Teaching Reform Research Planning Project of Xijing University (JGGH1511).

\section{REFERENCES}

[1] B. Nicholas, L. Garicano, R. Sadun, and J. V. Reenen, "The distinct effects of information technology and communication technology on firm organization," Management Science, vol. 60, no. 12, pp. 2859-2885, 2014.

[2] L. Chan, G. F. Peters, V. J. Richardson, and M. W. Watson, "The consequences of information technology control weaknesses on management information systems: The case of Sarbanes-Oxley internal control reports," Mis Quarterly, vol. 36, no. 1, pp. 179-203, 2012.

[3] T. Jochen, Tao Cheng, and Yihai Fang, "Location tracking and data visualization technology to advance construction ironworkers' education and training in safety and productivity," Automation in Construction, vol. 35, pp. 53-68, 2013.

[4] M. P. Gagnon, M. Desmartis, M. Labrecque, J. Car, C. Pagliari, P. Pluye, P. Frémont, J. Gagnon, N. Tremblay, and F. Légaré, "Systematic review of factors influencing the adoption of information and communication technologies by healthcare professionals," Journal of medical systems, vol. 36, no. 1, pp. 241-277, 2012.

[5] S. Dale, D. Havelka, and J. W. Merhout, "An analysis of attributes that impact information technology audit quality: A study of IT and financial audit practitioners," International Journal of Accounting Information Systems, vol. 13, no. 1, pp. 60-79, 2012.

[6] M. Sunil, A. R. Tafti, I. Bardhan, and J. M. Goh, "Information technology and firm profitability: mechanisms and empirical evidence," Mis Quarterly, vol. 36, no. 1, pp. 205-224, 2014.

[7] S. Aceng, A. Any Akhmad, "Development of assessment method for information technology and business," in 2014 International Conference on Electrical Engineering and Coputer Science, Denpasar (ID), pp. 53$58,2014$.

[8] J. C. Besley, and A. H. Tanner, "What science communication scholars think about training scientists to communicate," Science Communication, vol. 33, no. 2, pp. 239-263, 2011. 